\title{
THE EFFECT OF POINT EMITTER GEOMETRIC PARAMETERS ON DUSTFALL
}

\author{
WPLYW PARAMETRÓW GEOMETRYCZNYCH EMITORA PUNKTOWEGO \\ NA OPAD PYŁU
}

\begin{abstract}
In this paper, the modeling results are presented of point emitter geometric parameters determining the dispersion of dust pollution in the atmospheric air and finally also dustfall. The parameters include: the height and diameter of the emitter. Using the maps generated by "Ek100w" programme of Atmoterm company from Opole, Poland, an analysis of the PM10 dustfall value distribution on the analyzed area has been made. Fraction of dust - PM10 - was emitted from emitters of various working parameters. Three situations were analyzed: emission from a one-family (detached) building, from and industrial plant and from a power plant. Different heights and diameters for the above cases were analyzed. What results from the work, is that the mentioned parameters have a significant influence on the value of dustfall on the area surface at different distances from the emitter. With the increase of the height and diameter of the emitter, the values of dustfall decrease. The distance of the maximal values occurrence also increases. Results of similar analysis and available tools allow to design emission in practice, and thus allow a maximal limitation of ambient concentration of pollution and dustfall in areas especially exposed to industrial and superficial emission.
\end{abstract}

Keywords: dustfall, emitter (chimney) height, diameter of emitter, Pasquill's model

\section{Introduction}

One of the ways to limit the negative effect of pollution emitted to the atmospheric air are secondary methods used at the stage of waste gases emission. Adequate legal acts determine the permitted quantities of pollution which subjects are allowed to emit in a given unit of time and the permissible levels of chosen substances in the air, i.e. their quantities in a unit of air for a given area. An important component of comprehensive air preservation is the monitoring of ambient concentration of air pollution in a given area. One of the tools used for a complete analysis of the state of the atmospheric air pollution caused by emission of pollution from a complex of emitters is "Ek100w" programme of Atmoterm company. The calculations are made on the basis of Pasquill's model recommended in Poland as the model for the calculation of the influence of industrial plants' emission onto

\footnotetext{
1 Institute of Engineering and Environmental Protection, Faculty of Materials, Civil and Environmental Engineering, University of Bielsko-Biala, ul. Willowa 2, 43-300 Bielsko-Biała, Poland, phone +48 338279138 , email: mwierzbinska@ath.bielsko.pl
} 
the condition (quality) of atmospheric air. Other countries have different evaluation methods of the dustfall in the atmosphere [1-4].

\section{Emission, ambient concentration and dustfall}

In accordance with the Act of $27^{\text {th }}$ April 2001, Environmental Protection Law [5], emission is defined as direct or indirect introduction of pollution into the environment as a result of human activity. Emission is the quantity of pollution introduced to the atmospheric air within a given time. Emission is determined in the following units: $\mathrm{mg} / \mathrm{s}$, $\mathrm{kg} / \mathrm{h}$ and $\mathrm{Mg} /$ year.

Ambient concentration is the quantity of pollution received by the environment. It is a measure of the degree of pollution, defined as a concentration of pollutants in the air, expressed in the mass units of the given pollutant per unit of air volume $-\mu \mathrm{g} / \mathrm{m}^{3}$ or $\mathrm{ppm}$, $\mathrm{ppb}$. The evaluation of the level of substances in the air is made by comparing them with the permissible concentration values of the substances in the air [5].

Dustfall is the quantity of the solid substance polluting the atmosphere, emitted by the emitter, which falls onto the area unit of terrain within a year. The value is expressed with a unit of $\mathrm{g} / \mathrm{m}^{2}$ year. In Poland, PM10 (particles of diameter smaller than $10 \mu \mathrm{m}$ ) are especially monitored because they are particles that are suspended and can be breathed in by people.

\section{Factors influencing the spread of pollution in the air} factors:

The process of pollution dispersion in the atmosphere is determined by the following

- Meteorological factors (atmospheric turbulence, vertical thermal gradient, horizontal movement of air masses, thickness of mixing zone, precipitation, etc.)

- Topographical factors (area shape - topographic profile, type of land development aerodynamic surface roughness coefficient)

- Technical and technological factors (height and diameter of the emitter, speed of output and temperature of emitted gasses) [6].

An analysis has been made, in this article, of the influence of the technical factors, and especially of the height and diameter of the emitter, onto the isoline of dustfall in an area limited by the analysis net.

Waste gasses introduced into the air via chimneys are subject to the phenomenon of "plume rise" (Fig. 1). The plume rise - $\Delta h$ - is created as a result of the use of kinetic energy and the uplift pressure of the gas sent to the atmosphere. It lasts until the waste gases mix with the surrounding air. As a result, the gasses emitted from chimneys (stacks) behave as if they were emitted from height $H$ (Fig. 1), i.e. a level higher than the geometrical height of the chimney (stack) - $h$. The $H$ height is called the "effective emitter height" and determines the distance of the plume axis from the surface of the earth:

$$
H=h+\Delta h
$$

where: $H$ - emitter effective height [m], $h$ - emitter geometric height [m], $\Delta h$-plume rise of waste gasses $[\mathrm{m}]$.

There are three phases of the waste gases plume spread:

- Phase one - occurs directly after the gases leave the chimney (stack). The plume is almost vertical and has high kinetic energy. 
- $\quad$ Phase two - transitory - starts at the moment of a clear curvature of the trajectory and ends when the vertical component of the plume movement aliases with the vertical component of the wind velocity. The axis of the plume is almost horizontal.

- Phase three - the thickness of the plume, its temperature and velocity are identical to the very same factors of the atmospheric air. At this phase, the real process of pollution spread in the atmosphere begins. Here, the technical conditions of the emission, apart from its quantity and the type of contaminants, no longer have influence on the physical properties of the plume, while the meteorological and topographical factors are of decisive significance.

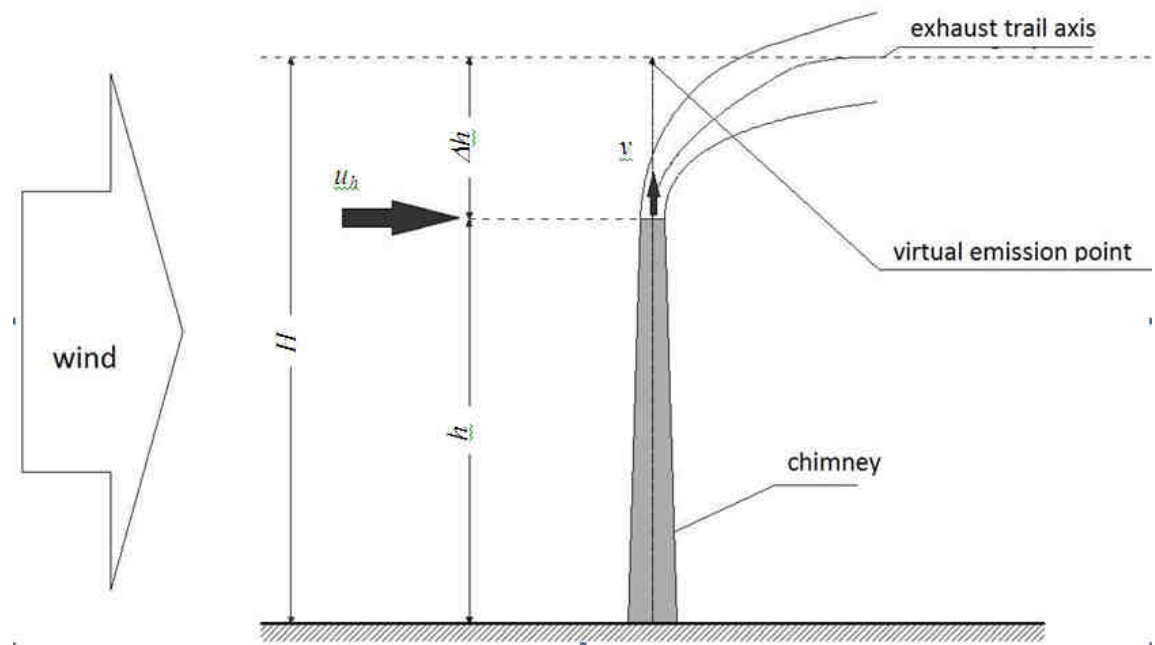

Fig. 1. Diagram of plume movement $\left(u_{h}\right.$ - wind velocity at the outlet of the emitter; $v$ - exit velocity of gases) [6]

\section{Methodology of the analysis of pollution spread in the air}

The analysis of the PM10 suspended dust in the air was carried out by calculating the value of dustfall in various distances from the emitter. Dustfall is the quantity of dust which falls on the area of one $\mathrm{m}^{2}$ within a year. As a tool, "Ek100w" programme of Atmoterm company was used, which made it possible to graphically present the results in the form of isolines on maps. The programme is based on Pasquill's model, recommended by the Ministry of Environment [7].

The Pasquill's equation is a solution to the reduced differential equation of the diffusion of pollution in a moving gas medium. It is applied in the case of point sources set in time, e.g. chimneys (stacks), air vents, ventilation ejectors. The result of the solution to Pasquill's equation is the concentration of pollution in every point of the calculation area. Order of the Minister of Environment of 26 January 2010 concerning the reference values for particular substances in the air describes the reference methodology of modelling levels of substances in the air and on the ground surface (dustfall) and equations for calculation [7]. The above methodology is used in the article. 
The "Ek100w" programme of Atmoterm S.A. is an all-purpose tool allowing the making of an analysis of the dispersion of pollution in the atmospheric air, emitted from individual or complex, point, linear or surface emitters.

The calculations have been done for the parameters presented in Tables 1 and 2. It was assumed that the emitter is an open (non-roofed) point emitter with the height of $10 \mathrm{~m}$ and an internal diameter of $1 \mathrm{~m}$. The parameters which were subject to the modelling were the height and the diameter of the emitter. The obtained calculation results of dust concentration in all the points of the calculation net have been visualised on maps in the form of isolines of dustfall on the calculation area. Then, an analysis of the isoline layout changes was made in the cases where various data was used for the same parameters. The analysis has been made for the heights of 4, 10, 50, 90, and 110 metres and for the diameters of $0.5,1,2$ and 3 metres. Values of PM10 dustfall on the surface of the earth were calculated at various distances and directions from the emitter. The calculation net was assumed to be at the level of the terrain, and the number of calculation points was approx. 2000.

Table 1

Analytical data statement

\begin{tabular}{|c|c|c|c|c|c|c|}
\hline $\begin{array}{c}\text { Individual } \\
\text { case }\end{array}$ & $\begin{array}{c}\text { Emitter } \\
\text { height } \\
\boldsymbol{H}[\mathbf{m}]\end{array}$ & $\begin{array}{c}\text { Inside diameter } \\
\text { of emitter } \\
\boldsymbol{D}[\mathbf{m}]\end{array}$ & $\begin{array}{c}\text { PM10 dust } \\
\text { emission } \\
\boldsymbol{E}[\mathbf{k g} / \mathbf{h}]\end{array}$ & $\begin{array}{c}\text { Output velocity } \\
\text { of waste gas } \\
\boldsymbol{v}[\mathbf{m} / \mathbf{s}]\end{array}$ & $\begin{array}{c}\text { Measure of } \\
\text { calculation net } \\
{[\mathbf{m}]}\end{array}$ & $\begin{array}{c}\text { Figure } \\
\text { number }\end{array}$ \\
\hline 1a. & 4 & 1 & 0.09 & 5 & 10 & Fig. 2 \\
\hline 1b. & 10 & 1 & 0.09 & 5 & 10 & Fig. 3 \\
\hline 2a. & 10 & 1 & 1 & 5 & 10 & Fig. 4 \\
\hline 2b. & 50 & 1 & 1 & 5 & 20 & Fig. 5 \\
\hline 3a. & 90 & 3 & 30 & 10 & 60 & Fig. 6 \\
\hline 3b. & 110 & 3 & 30 & 10 & 60 & Fig. 7 \\
\hline 4a. & 10 & 0.5 & 0.09 & 5 & 7 & Fig. 8 \\
\hline 4b. & 10 & 1 & 0.09 & 5 & 7 & Fig. 9 \\
\hline 5a. & 90 & 2 & 30 & 10 & 60 & Fig. 10 \\
\hline 5b. & 90 & 3 & 30 & 10 & 60 & Fig. 11 \\
\hline
\end{tabular}

1. and 4. - a one-family (detached) building

2. - an average industrial plant

3. and 5. - power plant

Table 2

Common parameters for each case

\begin{tabular}{|c|c|c|}
\hline Parameter & Unit & Value entered \\
\hline Ambient temperature & {$\left[{ }^{\circ} \mathrm{C}\right]$} & 8 \\
\hline Emission time within a year & {$[\mathrm{h}]$} & 8600 \\
\hline Aerodynamic surface roughness coefficient & {$[\mathrm{m}]$} & 0.5 \\
\hline Waste gases temperature & {$[\mathrm{K}]$} & 400 \\
\hline Height of calculation net & {$[\mathrm{m}]$} & 0 \\
\hline
\end{tabular}

\section{Results}

The results of modelling the dust pollution dispersion in the atmosphere have been presented on maps as isolines of dustfall. The calculation areas were made of 2000 up to 5000 calculation points, where the Ek100 programme calculated the values of dustfall for particular parameters of the emitter and exhaust gases. A visualisation was made using the calculation results, the outcome of which are the maps presented in Figures 2-11. 


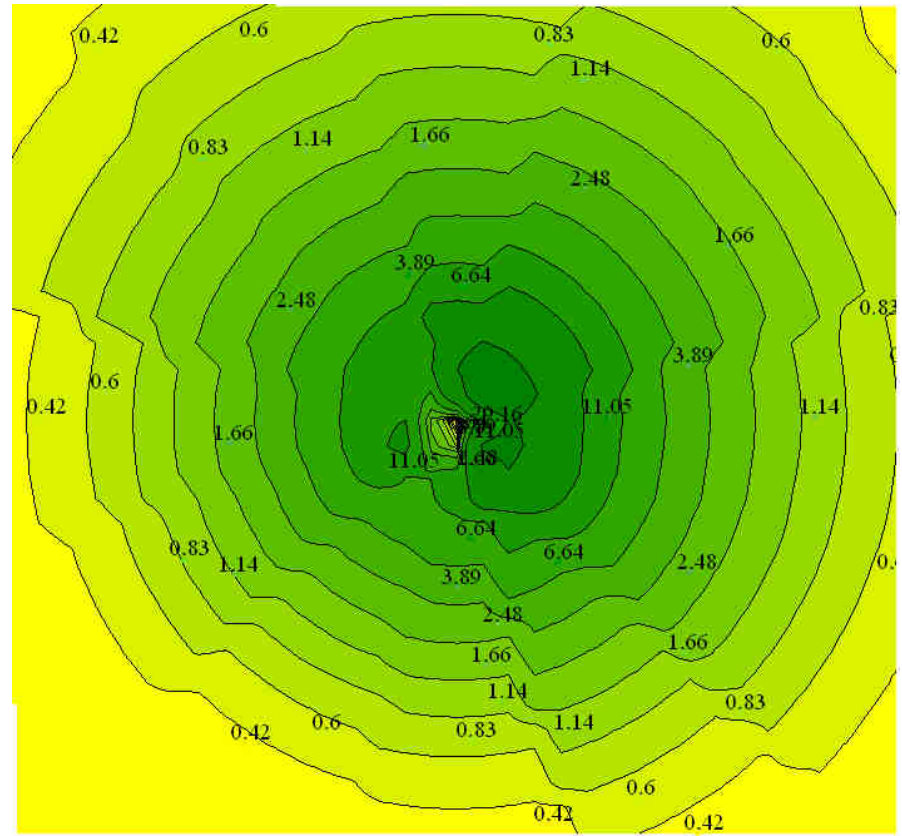

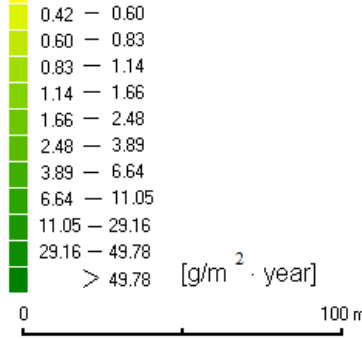

SOZAT 7 ATMOTERM

Fig. 2. Distribution map of dustfall isolines for a 4-metre-high emitter and PM10 dust emission of $0.09 \mathrm{~kg} / \mathrm{h}$
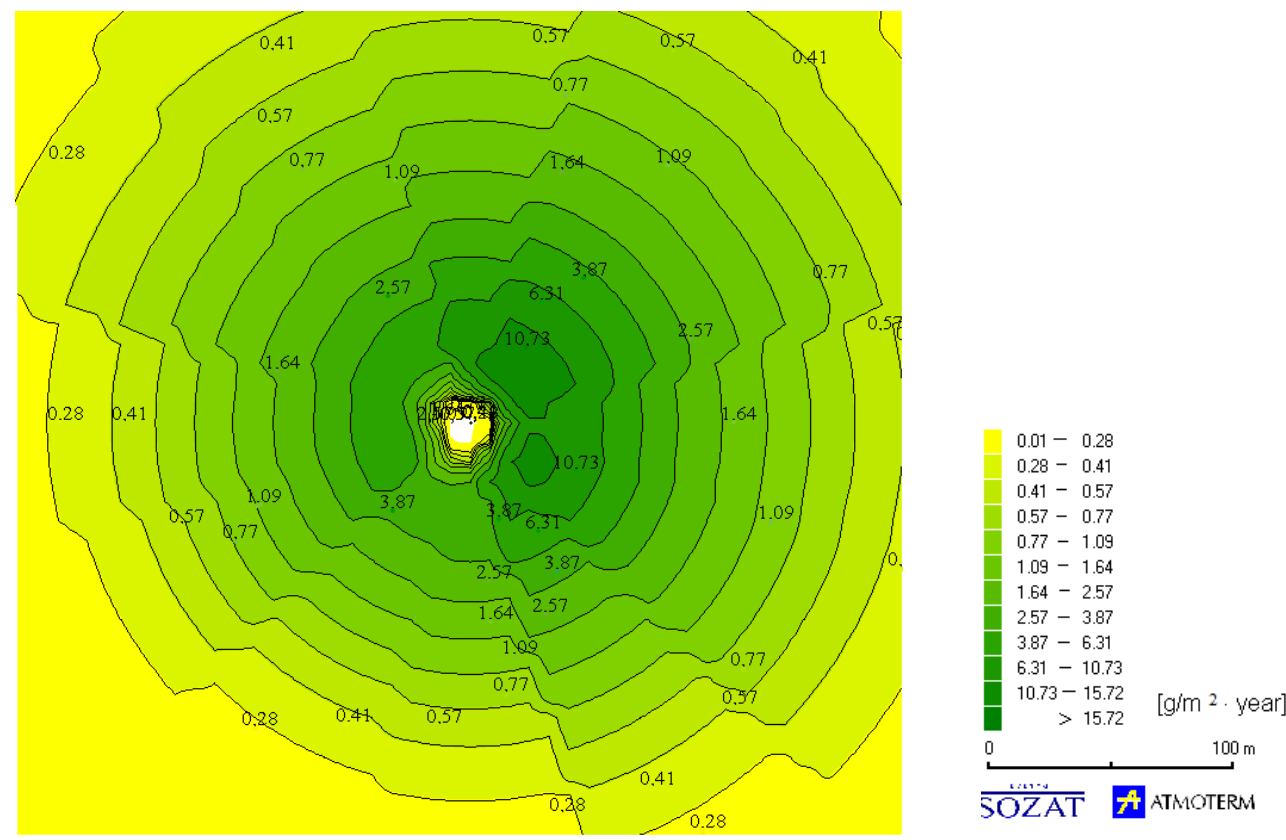

Fig. 3. Distribution map of dustfall isolines for a 10-metre-high emitter and PM10 dust emission of $0.09 \mathrm{~kg} / \mathrm{h}$ 

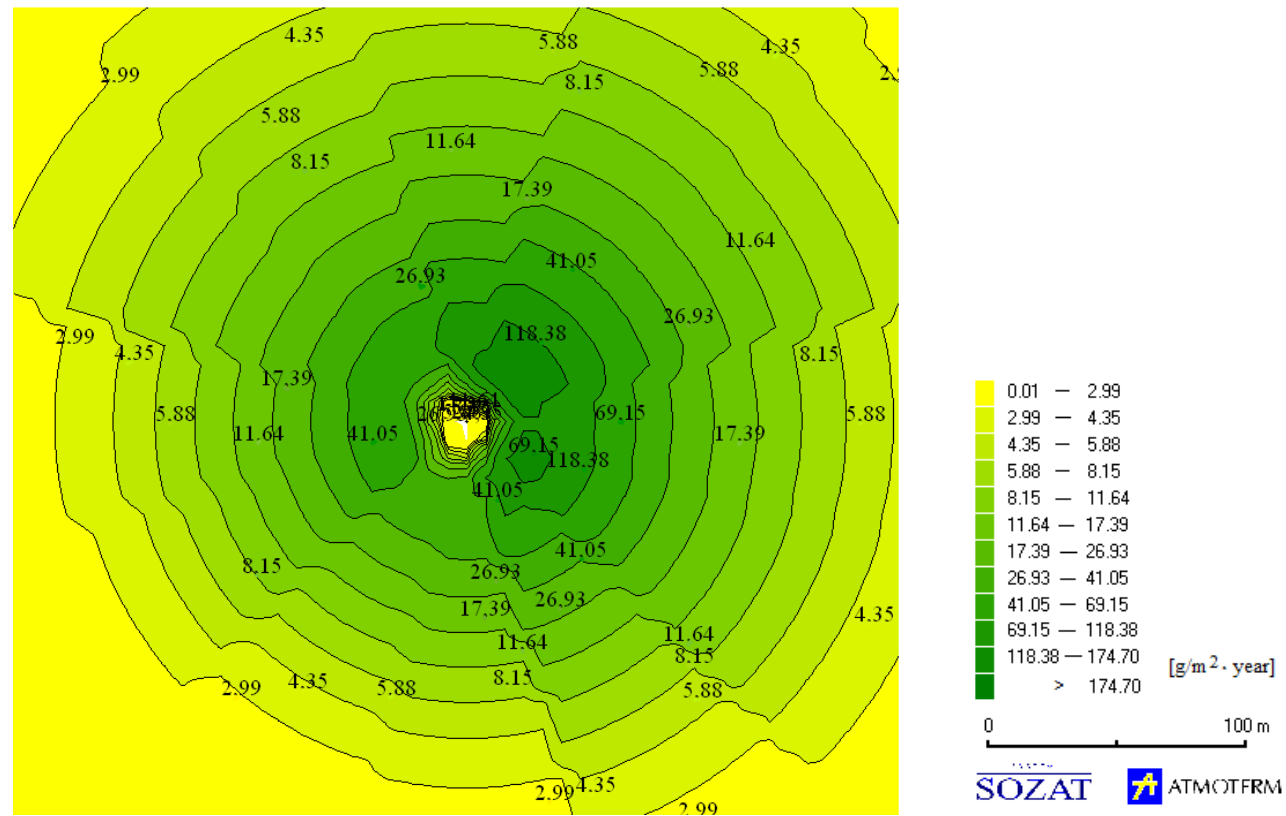

Fig. 4. Distribution map of dustfall isolines for a 10-metre-high emitter and PM10 dust emission of $1 \mathrm{~kg} / \mathrm{h}$

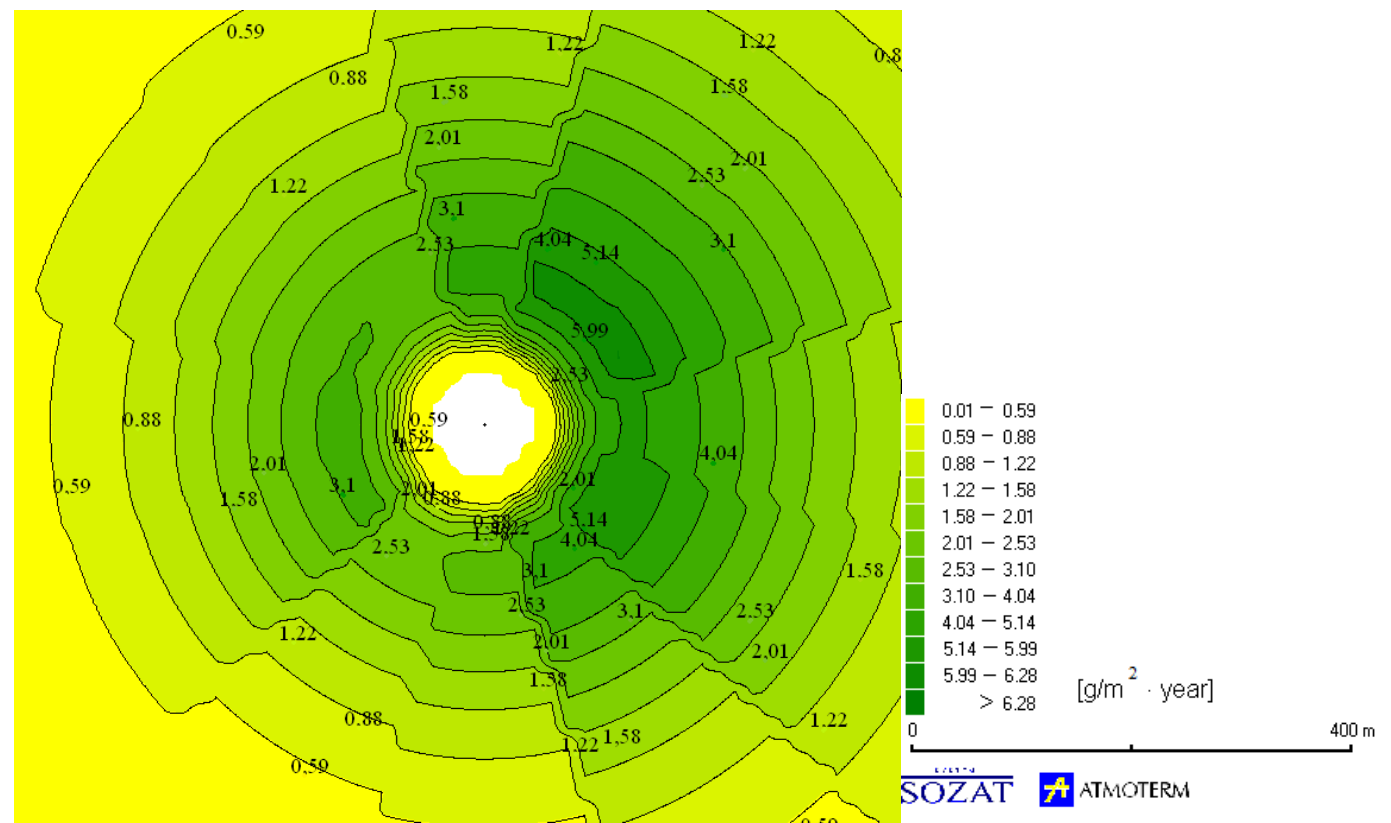

Fig. 5. Distribution map of dustfall isolines for a 50-metre-high emitter and PM10 dust emission of $1 \mathrm{~kg} / \mathrm{h}$ 

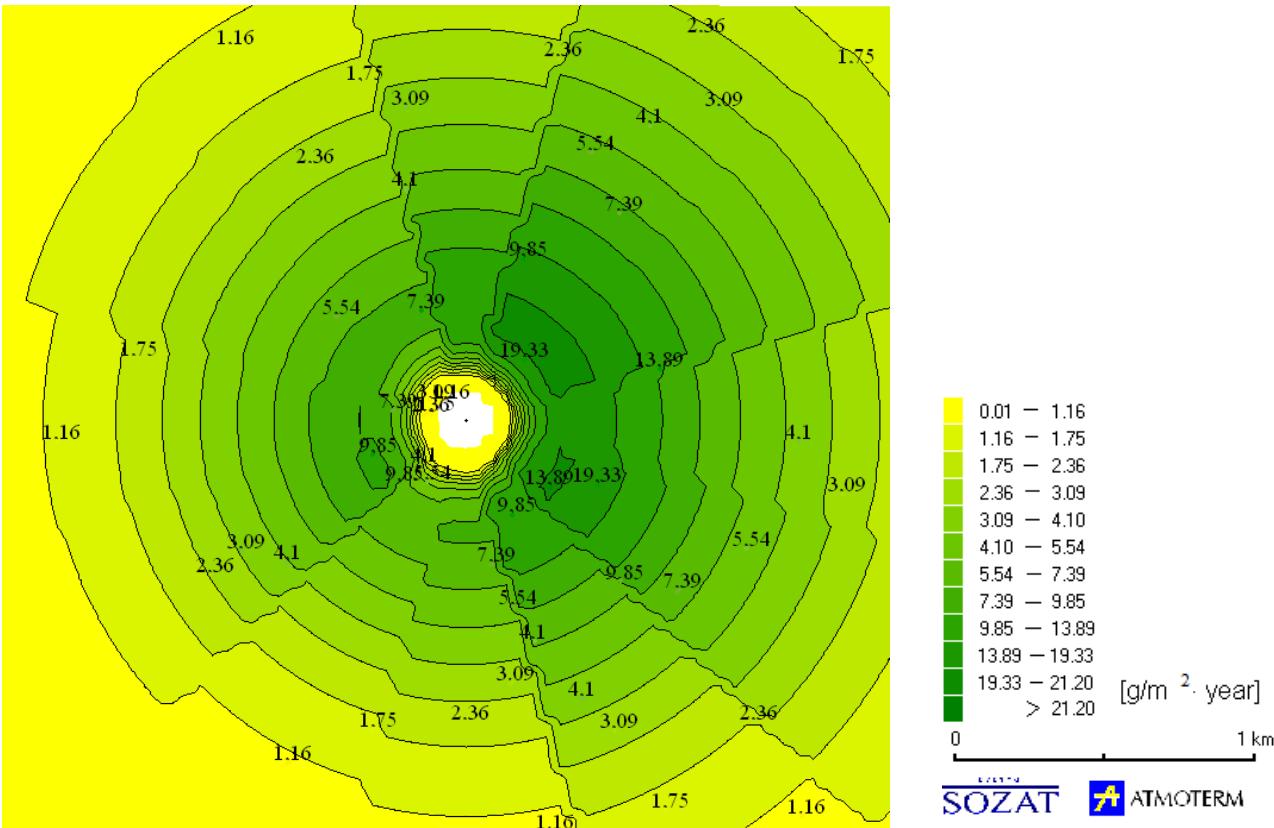

Fig. 6. Distribution map of dustfall isolines for a 90-metre-high emitter and PM10 dust emission of $30 \mathrm{~kg} / \mathrm{h}$
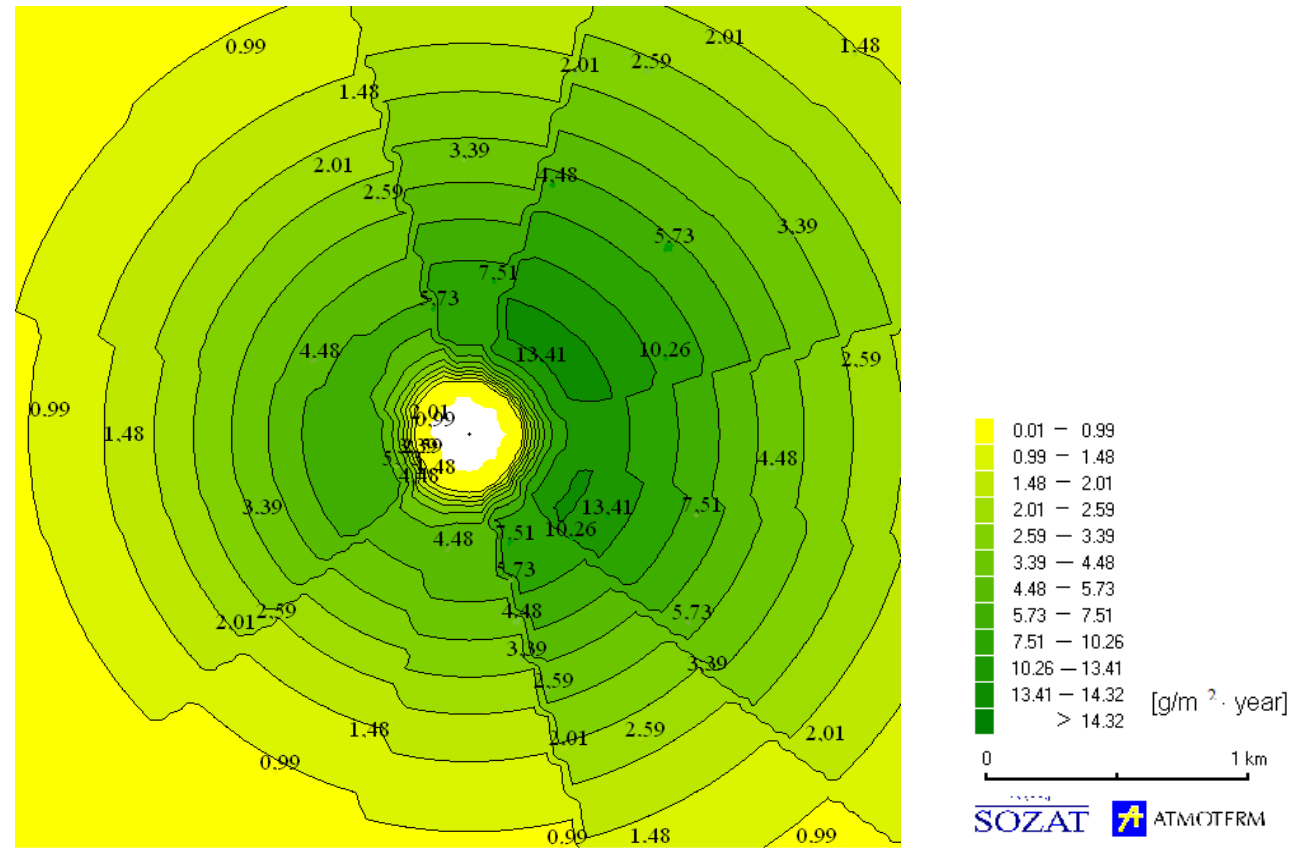

Fig. 7. Distribution map of dustfall isolines for a 110-metre-high emitter and PM10 dust emission of $30 \mathrm{~kg} / \mathrm{h}$ 


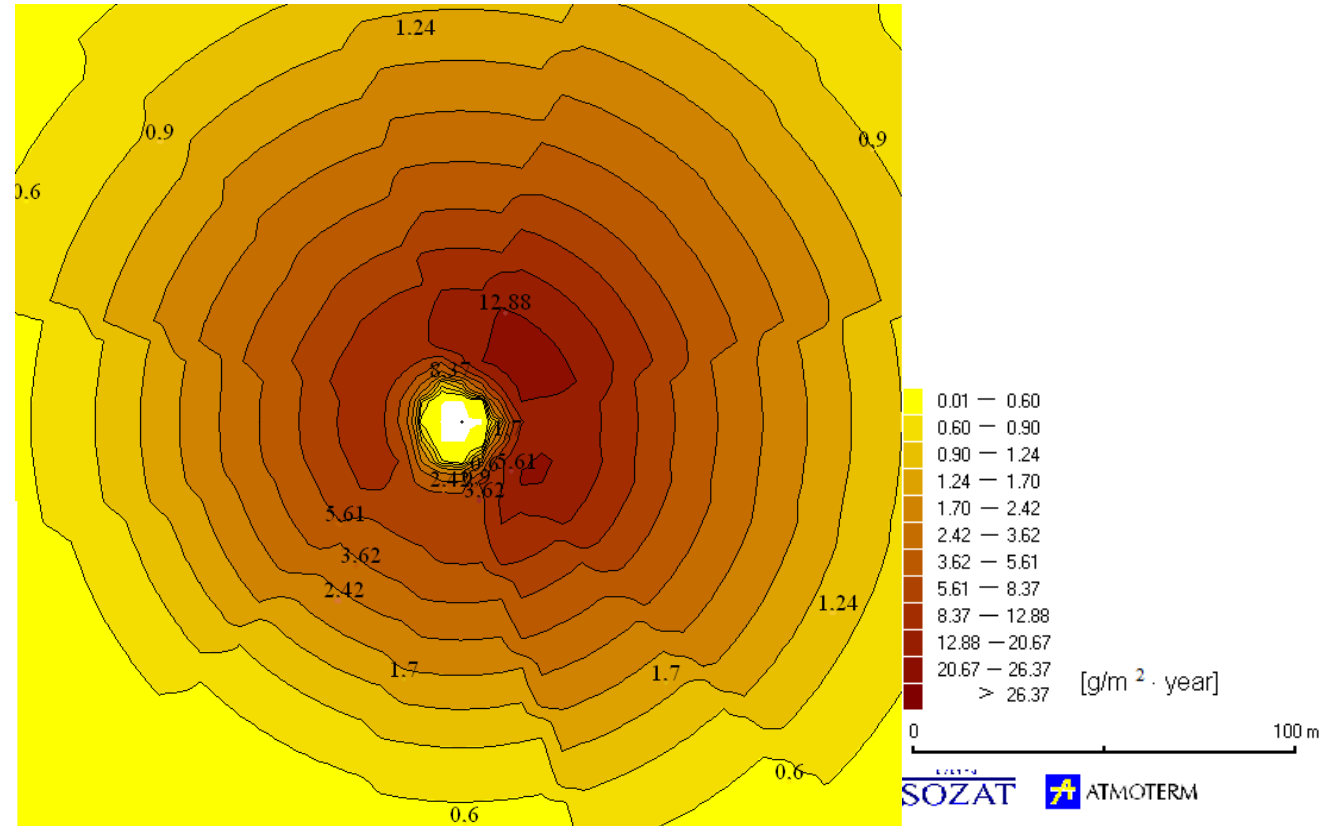

Fig. 8. Distribution map of dustfall isolines for an emitter with a diameter of $0.5 \mathrm{~m}$ and PM10 dust emission of $0.09 \mathrm{~kg} / \mathrm{h}$
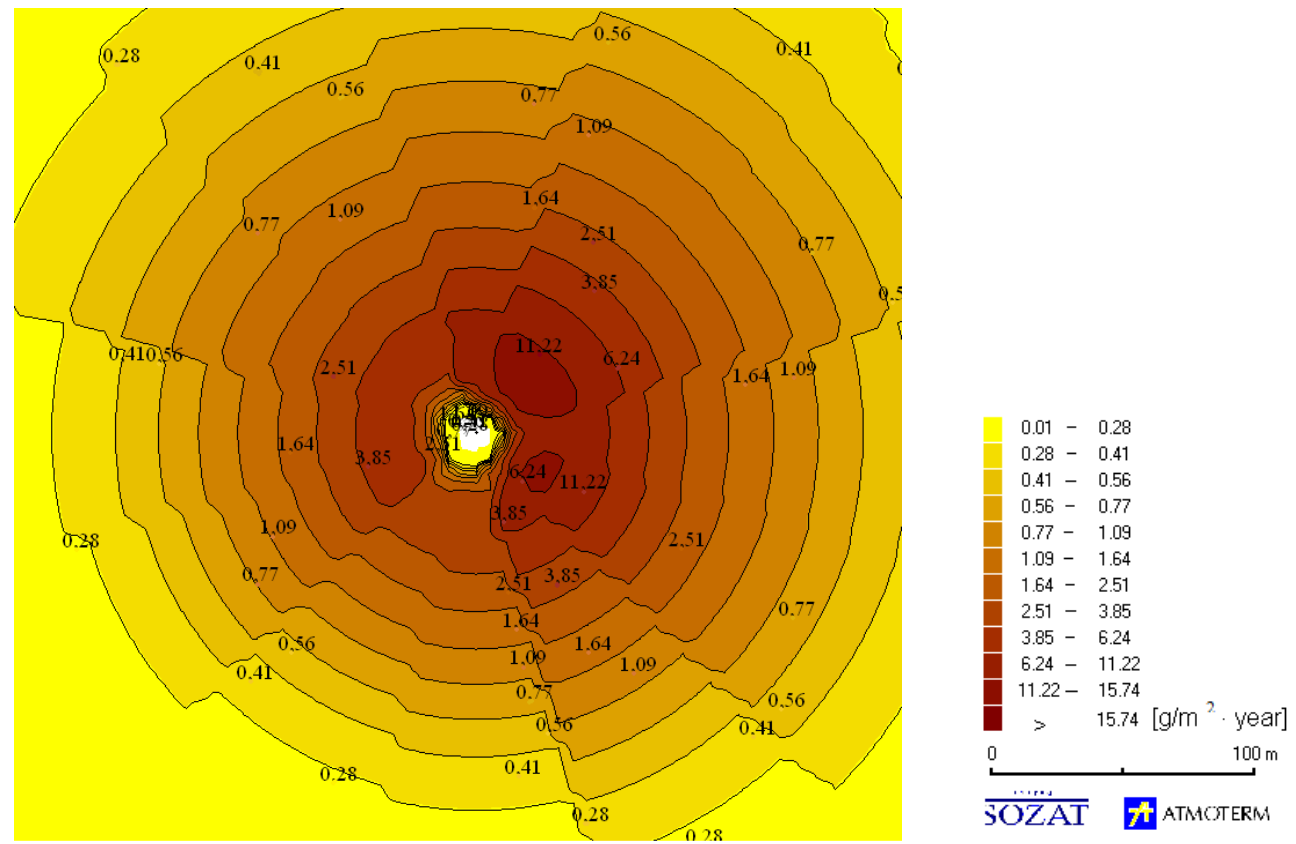

Fig. 9. Distribution map of dustfall isolines for an emitter with a diameter $1 \mathrm{~m}$ and PM10 dust emission of $0.09 \mathrm{~kg} / \mathrm{h}$ 


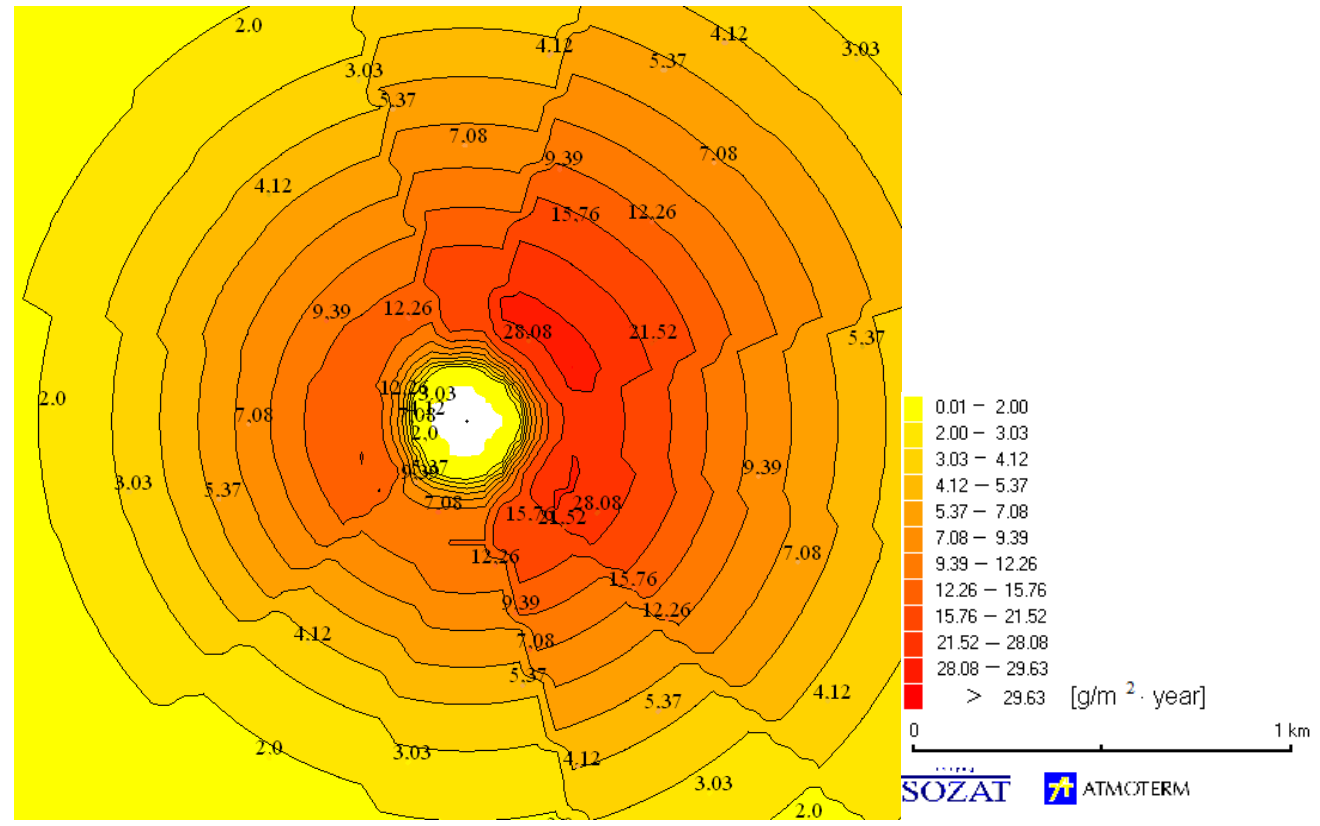

Fig. 10. Distribution map of dustfall isolines for an emitter with a diameter of $2 \mathrm{~m}$ and PM10 dust emission of $30 \mathrm{~kg} / \mathrm{h}$

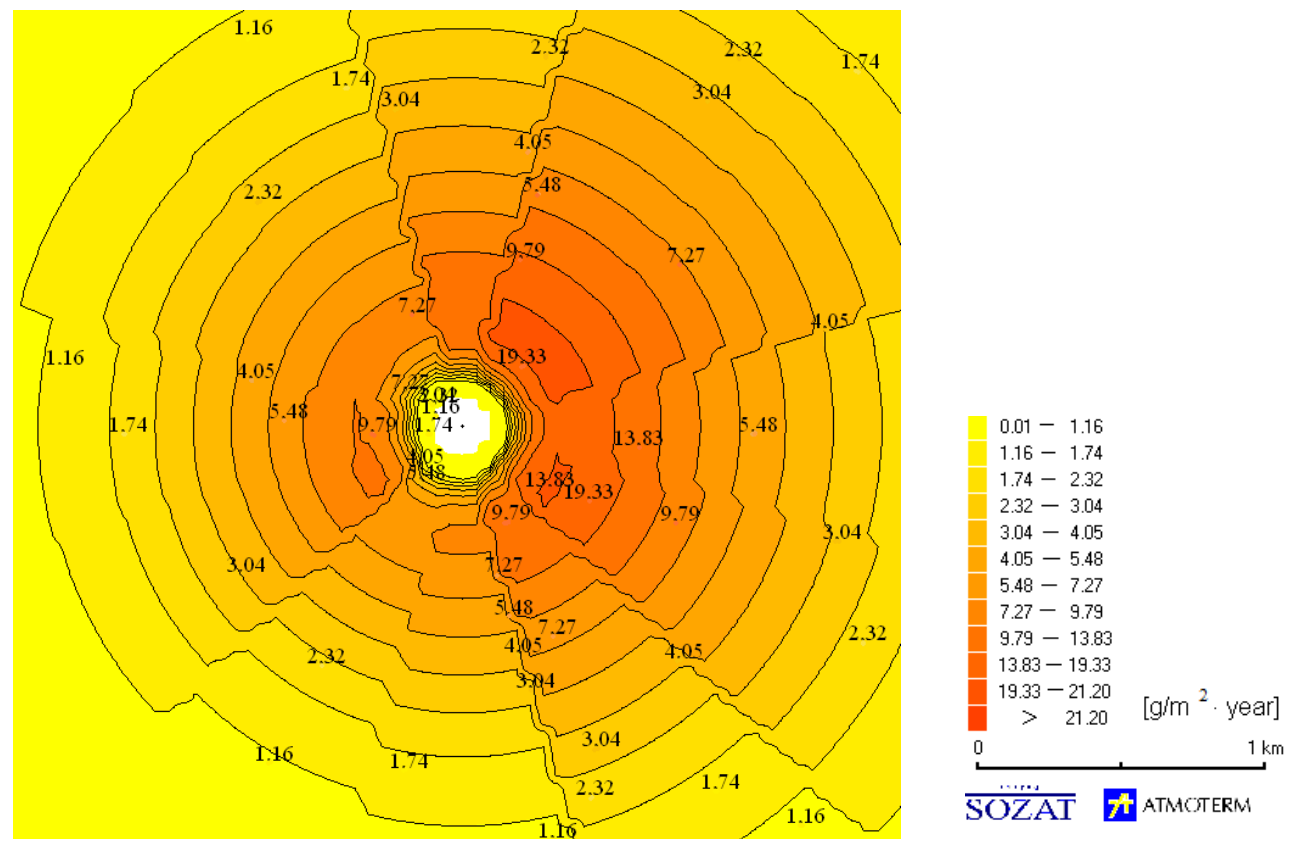

Fig. 11. Distribution map of dustfall isolines for an emitter with a diameter of $3 \mathrm{~m}$ and PM10 dust emission of $30 \mathrm{~kg} / \mathrm{h}$ 


\section{Analysis and elaboration on the results}

The analysis concerns variations of dustfall in various distances from the emitter, in indicated points of the calculation net, assumed for individual cases (Tables 1 and 2). The article presents two characteristic results for an extreme situation in each case (Table 3), e.g. in the case of a point emitter in a one-family household: emitter with the height of $4 \mathrm{~m}$, for a low building, and $10 \mathrm{~m}$ for a high one, and for a production plant: 10 and $50 \mathrm{~m}$, and for a power plant: 90 and $110 \mathrm{~m}$.

Analysing the impact of geometric parameters of the emitter onto the distribution of dustfall in the area of this emitter's influence $(50 \mathrm{~h})$ [7], the significance of the geometric height of the emitter and its diameter have been considered. The results prove unequivocally that the impact of the parameters is significant, not only as regard to the value of dustfall, but also as regard to the distance from the emitter in which the dust will fall onto the surface of the ground.

Figure 2 presents the distribution of dustfall isolines for an emitter situated on a roof of a low one-family building, with an outlet at the height of $4 \mathrm{~m}$ and a diameter of $1 \mathrm{~m}$. In such a case, the dust emitted together with the waste gases falls onto the surface of the ground right next to the building, which constitutes an immediate health hazard for the inhabitants of the property. The area in which most of the dust will fall is from 17 to 34 metres from the emitter, in the distance depending on the wind rose for the given area. The dustfall here reaches the values of 29 to $49 \mathrm{~g} / \mathrm{m}^{2}$ year, with a value of dust emission assumed for a coal-fired furnace. At the distance higher than $240 \mathrm{~m}$ from the emitter, the dustfall is minimal. Comparing Figures 2 and 3, it is visible that if the emitter is raised by $6 \mathrm{~m}$, the pollution will fall further from the emitter and the maximal concentration will be lower. Figure 3 shows a case of an emitter with the height of $10 \mathrm{~m}$. The other parameters are kept unchanged, as in the previous case. Here, the dust starts to fall at the distance of $14 \mathrm{~m}$ from the emitter. The area with maximal values is situated locally at the distance from 25 to $64 \mathrm{~m}$ from the emitter, where the dustfall assumes values above $15 \mathrm{~g} / \mathrm{m}^{2}$ year. The dustfall disappears at the distance of approx. $340 \mathrm{~m}$ from the emitter. In the case of low, single-family houses, the most polluted areas will be the ones within the same property, while in the case of higher emitters, the highest dust concentration will be in neighbouring areas. However, the concentration will be twice as low.

Figures 4 and 5 present a situation of an average industrial plant. Cases were analysed where the emitter has the height of 10 and $50 \mathrm{~m}$ with a diameter of $1 \mathrm{~m}$. In the case where the emitter has the height of $10 \mathrm{~m}$ (Fig. 4), the dust pollution fall to the surface of the ground at the distance of approx. $13 \mathrm{~m}$ from the emitter. The maximal dustfall is located within the distance of 26 to $56 \mathrm{~m}$ from the emitter and reaches the values of the order of $170 \mathrm{~g} / \mathrm{m}^{2}$ year. However, if the emitter has the height of $50 \mathrm{~m}$ (Fig. 5), the dust does not fall until it reaches the distance of $80 \mathrm{~m}$ from the emitter. It is caused by the bigger "silence zone" around the emitter, which rises along with the height of the emitter, which means with the height of the exhaust gases plume rise and of the effective height of the emitter. The area where the largest dustfall is observed spreads within the distance of 160 to $212 \mathrm{~m}$ from the emitter. The dustfall disappears above $570 \mathrm{~m}$ away from the emitter, while in the previous case $(10 \mathrm{~m})$ it is approx. $350 \mathrm{~m}$, and the maximal concentration is approx. 20 times lower.

Another case concerns high emitters, which are characteristic of power plants. The article includes results from the height of 90 and $110 \mathrm{~m}$ and the diameter of $3 \mathrm{~m}$. The 
assumed dust emission is assumed at the level of $30 \mathrm{~kg} / \mathrm{h}$, and the velocity of exhaust gases $v=10 \mathrm{~m} / \mathrm{s}$. Analysing Figure 6, it is noticeable that the "silence zone" is approx. $200 \mathrm{~m}$, while in the case of $h=110 \mathrm{~m}$ (Fig. 7) it is approx. $250 \mathrm{~m}$. The highest dustfall occurs within the distance of 450 to $556 \mathrm{~m}$ from the emitter with the height of $90 \mathrm{~m}$ and is approx. $21 \mathrm{~g} / \mathrm{m}^{2}$.year, and approx. $14 \mathrm{~g} / \mathrm{m}^{2}$.year at the distance of 488 to $732 \mathrm{~m}$ for $h=110 \mathrm{~m}$. At the lower height of the emitter, the dustfall disappears at the distance of approx. $2 \mathrm{~km}$, while at the higher one - approx. $3 \mathrm{~km}$ from the emitter. The maximal values of dustfall vary between the cases mentioned above by approx. $7 \mathrm{~g} / \mathrm{m}^{2}$ year.

Figures 8-11 concern the modelling of the diameter of the emitter and the changes of dust dispersion in the atmosphere. Figure 8 presents the situation of a single-family household with emitter height of $10 \mathrm{~m}$ and a diameter of $0.5 \mathrm{~m}$. As one can see, the dust falls at the distance of $12 \mathrm{~m}$ from the emitting chimney. The dustfall reaches its maximal values at the distances of 23 to $44 \mathrm{~m}$ from the emitter, and they are above $26 \mathrm{~g} / \mathrm{m}^{2}$.year. In the situation presented in Figure 9, where the diameter of the emitter is changed from 0.5 to $1 \mathrm{~m}$, the highest dustfall is approx. $15 \mathrm{~g} / \mathrm{m}^{2}$.year at the distance of 33 to $70 \mathrm{~m}$ from the centre of emission. The radius up to which dustfall is not registered is, in both cases, several metres from the emitter, while the dustfall disappearance distance is approx. $200 \mathrm{~m}$ for the diameter of the emitter of $0.5 \mathrm{~m}$ and over $320 \mathrm{~m}$ for the emitter diameter of $1 \mathrm{~m}$.

The modelling of dust pollution dispersion in the atmosphere depending on the diameter of emitter at a power plant is presented in Figures 10 and 11. The height of the stacks was $90 \mathrm{~m}$, and the dust emission value was $30 \mathrm{~kg} / \mathrm{h}$. Figure 10 depicts the situation where the emitter diameter is $2 \mathrm{~m}$. In this case, dust starts falling onto the surface of the ground about $175 \mathrm{~m}$ from the emitter, reaching the maximal values of $29 \mathrm{~g} / \mathrm{m}^{2}$.year at the distances from 386 to $490 \mathrm{~m}$ from the emitter. The dustfall disappears at a distance higher than $2.3 \mathrm{~km}$ from the emission centre. If the diameter of the stack is increases by $1 \mathrm{~m}$ (Fig. 11), the maximal dustfall decreases to the value of $21 \mathrm{~g} / \mathrm{m}^{2}$ year, and the distance of its occurrence increases to 400-614 m from the emitter. In this case, dustfall disappears after over $2.7 \mathrm{~km}$ from the emitter. Thus, it can be noticed that by increasing the diameter of the power-plant emitter by $1 \mathrm{~m}$, a decrease of the maximal dustfall values and a slight increase of the "silence zone" around the emitter is obtained.

Table 3

Results for each cases

\begin{tabular}{|c|c|c|c|c|}
\hline Individual case & $\begin{array}{c}\text { Height of the emitter } \\
\boldsymbol{H}[\mathbf{m}]\end{array}$ & $\begin{array}{c}\text { Inside diameter } \\
\text { of the emitter } \\
\boldsymbol{D}[\mathbf{m}]\end{array}$ & $\begin{array}{c}\text { Maximal value } \\
\text { of dustfall } \\
{\left[\mathbf{g} / \mathbf{m}^{\mathbf{2}} \mathbf{y e a r}\right]}\end{array}$ & $\begin{array}{c}\text { Distance from the emitter } \\
{[\mathbf{m}]}\end{array}$ \\
\hline 1a. & 4 & 1 & 29 & $17-34$ \\
\hline 1b. & 10 & 1 & 15 & $25-64$ \\
\hline 2a. & 10 & 1 & 170 & $26-56$ \\
\hline 2b. & 50 & 1 & 6 & $160-212$ \\
\hline 3a. & 90 & 3 & 21 & $450-556$ \\
\hline 3b. & 110 & 3 & 14 & $488-732$ \\
\hline 4a. & 10 & 0.5 & 26 & $23-44$ \\
\hline 4b. & 10 & 1 & 16 & $33-70$ \\
\hline 5a. & 90 & 2 & 30 & $386-490$ \\
\hline 5b. & 90 & 3 & 21 & $400-614$ \\
\hline
\end{tabular}




\section{Conclusions}

1. Values of PM10 dustfall on the earth surface are inversely proportional to the emitter geometric height, i.e. the values decrease when the emitter height $h$ is increased. If, in a one-family (detached) building case, the height of the emitter is increased by $6 \mathrm{~m}$, the maximal value of dustfall is 2 times lower. If, in an industrial plant case, the height of the emitter is increased from 10 to $50 \mathrm{~m}$, the maximal value of dustfall will be 28 times lower. Similarly, if the height of the power plant emitter is increased by $20 \mathrm{~m}$, the maximal value of dustfall will be more than 2 times lower.

2. The distance of the area with maximum accumulation of dust pollution is located further from the emitter when the emitter height is higher: for $h=4 \mathrm{~m}$ the distance will be $17 \mathrm{~m}$, for $h=50 \mathrm{~m}$ the distance will be $160 \mathrm{~m}$, and for $h=110 \mathrm{~m}$ it will be $488 \mathrm{~m}$.

3. Values of the dustfall decrease while the emitter diameter increases, i.e. the dustfall is inversely proportional to the inside diameter of the emitter. If the diameter is $0.5 \mathrm{~m}$, the maximal dustfall will be $26 \mathrm{~g} / \mathrm{m}^{2}$.year, and if it is $1 \mathrm{~m}$, the maximal dustfall will be $16 \mathrm{~g} / \mathrm{m}^{2} \cdot$ year.

4. The increase of the emitter diameter results in a slight increase of the "silence zone" around the emitter and an increase of the distance of the area where values of PM10 dustfall on the earth surface are maximal. The maximal dustfall appears at the distance of $23-44 \mathrm{~m}$ from the emitter when its diameter is $0.5 \mathrm{~m}$, and $33-70 \mathrm{~m}$ when it is $1 \mathrm{~m}$. Similarly, when the diameter is increased from $2 \mathrm{~m}$ to $3 \mathrm{~m}$ the maximal dustfall will increase by dozens of meters.

\section{References}

[1] Technical Guidance Note (Monitoring) M17, Monitoring Particulate Matter in Ambient Air around Waste Facilities. Environment Agency: Version 2; July 2013. https://www.gov.uk/government/uploads/system/ uploads/attachment_data/file/301206/TGN_M17_Monitoring_of_particulate_matter_in_ambient_air_around _waste_facilities.pdf

[2] Naddafi K, Nabizadeh R, Soltanianzadeh Z, Ehrampoosh MH. Evaluation of dustfall in the air of Yazd. Iran J Environ Health Sci Eng. 2006;3(3):161-168. http://www.bioline.org.br/pdf?se06023

[3] Herrick RA. Recommended standard method for continuing dust fall survey (APM-1, Revision 1). J Air Pollut Control Assoc. 2012;16(7):372-377. DOI: 10.1080/00022470.1966.10468490.

[4] Esmen NA. A direct measurement method for dustfall. J Air Pollut Control Assoc. 2012;23(1):34-36. DOI: $10.1080 / 00022470.1973 .10469745$.

[5] DzU 2001, Nr 62, poz. 627, Ustawa z dnia 27 kwietnia $2001 \mathrm{r}$. Prawo ochrony środowiska. (Act of $27^{\text {th }}$ April 2001, Environmental Protection Law, J Laws No. 62, item 627). http://isap.sejm.gov.pl/ DetailsServlet?id=WDU20010620627.

[6] Janka RM. Zanieczyszczenia pyłowe i gazowe, Podstawy obliczania i sterowania poziomem emisji. (Dust and gas pollution, rudiments of calculation and controlling the level of emissions). Warszawa: Wyd Nauk PWN; 2014.

[7] DzU 2010, Nr 16, poz. 87, Rozporządzenie Ministra Środowiska z dnia 26 stycznia 2010 r. w sprawie wartości odniesienia dla niektórych substancji w powietrzu. (Order of the Minister of Environment of 26 January 2010 concerning the reference values for particular substances in the air). http://isap.sejm.gov.pl/ DetailsServlet?id=WDU20100160087. 


\title{
WPLYW PARAMETRÓW GEOMETRYCZNYCH EMITORA PUNKTOWEGO NA OPAD PYŁU
}

\author{
Instytut Ochrony i Inżynierii Środowiska, Wydział Inżynierii Materiałów, Budownictwa i Środowiska \\ Akademia Techniczno-Humanistyczna w Bielsko-Białej
}

\begin{abstract}
Abstrakt: W artykule zaprezentowano wyniki modelowania parametrów geometrycznych emitora punktowego determinujących rozprzestrzenianie się zanieczyszczeń w powietrzu atmosferycznym, a w konsekwencji również opad pyłu. Do parametrów tych należą: wysokość i średnica emitora. Korzystając z map wygenerowanych przez program Ek100w firmy Atmoterm z Opola, przeprowadzono analizę rozkładu wartości opadu pyłu PM10 na analizowanym obszarze. Frakcja PM10 emitowana była z emitorów o różnych parametrach roboczych. Analizowano 3 sytuacje: emisję $\mathrm{z}$ gospodarstwa jednorodzinnego, $\mathrm{z}$ zakładu przemysłowego oraz z elektrociepłowni. Dla tych przypadków rozpatrywano różne wysokości i średnice emitora. $Z$ artykułu wynika, że wymienione parametry mają znaczny wpływ na ilość pyłu osadzającego się na powierzchni gruntu w różnych odległościach od emitora. Wyniki podobnych analiz oraz dostępne narzędzia pozwalają na projektowanie emisji w praktyce, a tym samym maksymalne ograniczanie imisji oraz opadu zanieczyszczeń na terenach szczególnie narażonych na emisję przemysłową oraz niską emisję.
\end{abstract}

Słowa kluczowe: opad pyłu, wysokość emitora, średnica emitora, model Pasquilla 